\title{
Industry Knowledge Sources and the Role of Universities
}

By: John Rees and Keith Debbage

Rees, J. and K. Debbage, (1992) “Industry Knowledge Sources and the Role of Universities," Review of Policy Research, 11(1): 6-25.

Made available courtesy of Wiley-Blackwell. The definitive version is available at: http://onlinelibrary.wiley.com/doi/10.1111/j.1541-1338.1992.tb00329.x/full

***Reprinted with permission. No further reproduction is authorized without written permission from Wiley-Blackwell. This version of the document is not the version of record. Figures and/or pictures may be missing from this format of the document. $* * *$

\begin{abstract}
:
In recent years, rapid growth has occurred in both the number and diversity of universityindustry programs in the United States. While little comprehensive assessment of these programs exists to date, this paper argues that a systematic empirical analysis of a company's perception of universities as knowledge sources is critical to a clear understanding of the new alliances between industry and academia. From a survey of 216 companies, a pattern emerges where the sources of technical knowledge perceived as important by industry are complex and highly interrelated, and they also vary according to the characteristics of companies, especially size. It is seen that university research rather than universities as institutions per se are critical ingredients to the development of new products and production processes.
\end{abstract}

Keywords: high-technology industry | university-industry programs | industry and academic partnerships | technical knowledge | university research | product innovation

\section{Article:}

The growth of high-technology industry and the reassessment of the relative value of research and development (R\&D) programs in the past decade has led to the realization that the United States requires an emphasis on long-term research programs and education to maintain a competitive advantage (Porter, 1990). Consequently, in an attempt to provide a favorable climate to facilitate these needs there has been a rapid growth in both the number and diversity of university-industry programs and technology-based economic development policies around the country (National Science Board, 1982; Rees, 1986; Schmandt and Wilson, 1990). Despite the proliferation of both formal and informal university-industry initiatives, very little comprehensive assessment of the linkage between technological innovation and academic research has been reported, with some notable exceptions (Lambright and Teich, 1989; Berman, 1990; Feller; 1990a, 1990b; and Mansfield, 1991). 
The purpose of this paper is first to provide a more systematic and comprehensive overview of the perception and experiences of industry with universities as sources of technical knowledge vis-a-vis alternative sources of knowledge (e.g., research and development, suppliers, licensed technologies). A second objective involves relating how companies perceive universities as sources of technical knowledge to both a company's attitude towards locations with strong university-industry interactions and also to the level of company involvement in cooperative projects with universities. Finally, the role of company size in shaping both a company's perception of universities as a source of knowledge and company satisfaction levels will be investigated.

\section{BACKGROUND TO RESEARCH}

According to Feller (1990a), the formation of "new alliances" between universities and industry has become an increasingly important aspect of many company-level R\&D programs. However, "university-industry partnerships are emerging amidst a complex and fluid period in which federal, state, regional, and local government, industry, and university roles and relationships related to research, technological development, and commercialization are being redefined" (Feller, 1990a, p. 315). Many issues have yet to be worked out by the interested parties including: intellectual property rights, conflicts of interest, and the appropriate institutional structures to facilitate university-industry collaboration. However, "the climate for cooperation is widely seen to have improved, and the means to have been found to overcome many, if not all, impediments to university-industry relationships" (Feller, 1990a, p. 314).

A critical element of the broad sweep of university-industry alliances involves the manner in which industry perceives universities as sources of technical knowledge in the development of new products and production processes. In an increasingly information-intensive economy, where research and education are critical variables for maintaining a competitive advantage (particularly through the production of knowledge or "thoughtware" that has commercial applications) this issue is likely to take on added significance. Furthermore, recent empirical evidence suggests that in certain industries "the contribution of academic research to industrial innovation has been considerable" (Mansfield, 1991, p. 11). In a study of industry interaction with university and federal laboratories, Roessner and Bean (1990) argue that academia has become an increasingly important part of industrial research and development programs. They also empathize with the notion that access to networks of academic researchers working at the forefront of "knowledge" can be highly beneficial to companies.

However, "contemporary demands for access to university knowledge and research constitute distinctly new pressures on universities, mating changes we are only just beginning to see, let alone understand" (Paget, 1990, p. 345). For example, it is unclear what alternative sources of technical knowledge companies are considering in the development of new products and production processes, and it is also unclear whether some broader characteristics of universityindustry interaction can significantly affect how universities $a=$ perceived as sources of 
knowledge. Effective answers to these questions are made more difficult by the absence of a consensus on the most effective model of university-industry cooperation. For example, during the formative years of the NSF University-Industry Cooperative Research Centers program, "no preconceived notion (existed) of which model of university-industry cooperation would prove to be most effective" (Roessner, 1989, p. 349, italics added). According to Roessner, it was only after some time that the university-based research consortia gradually emerged as the most successful approach. Also, Goldstein and Luger (1990) stressed the diversity of approaches involving universities as instruments of technology-based economic development policy. These approaches included licensing and patenting assistance, technical and managerial assistance, small business assistance centers, equity investments, specialized laboratories and facilities, research parks, incubators, and joint research between private industry and universities.

Given the diversity of approaches in university-industry relationships, this paper argues that a systematic empirical analysis of a company's fundamental perception of universities as knowledge sources is critical to a clearer understanding of the wide-ranging "new alliances" (Dimancescu and Botkin 1986) that are emerging between industry and academia. It will also be argued that university research rather than universities as institutions per se ate critical ingredients in the development of new products and production processes by the private sector. Finally, it will be awed that larger companies (in terms of sales volume and employment levels) are more likely to link-up with universities than are smaller companies which should be of concern to state policy-makers who see university relations with small business as an important variable in local economic development. In terms of policy implications, economic development strategies that depend on productive university-industry linkage as the catalyst for generating "spin-off" development may be doomed to failure if a clearer understanding is not forthcoming of which companies are most apt to perceive universities favorably as important sources of knowledge.

\section{RESEARCH APPROACH}

A recent study of industry relationships with state-funded technology development programs provided the opportunity to examine how companies perceived the role of universities as sources of technical knowledge vis-a-vis other sources of technical knowledge (Rees, 1989, 1991). Based on a series of interviews with directors of state-based economic and technology development programs, several major industrial sectors were identified as frequent participants in research programs that involved microelectronics and computer aided manufacturing. These industry categories included: metal working machinery (SIC 354), office and computing machinery (SIC 357), electronic components and accessories (SIC 367), and aircraft and parts (SIC 372). By focusing on economic sectors that are involved in micro-electronics and computer-aided manufacturing, it is possible to analyze how some of the most innovative sectors within American manufacturing today perceive universities as sources of technical knowledge. 
From these SIC groups, an adjusted population of 1024 companies were identified and surveyed from the 1986DUNS file of the Dun and Bradstreet Corporation. The Dun and Bradstreet listings were used because they still remain the best national directory of manufacturing establishments available to researchers, even though the accuracy of this data can still be questioned in studies of job creation.

After an initial mailing to vice presidents of production and/or engineering, and follow up telephone checks, complete information was obtained on 216 of the 1024 companies. A response rate of $21 \%$ is good compared to other surveys of this kind when completion depends on the cooperation of busy corporate executives. The 216 respondents represent a relatively large data set that gives us the opportunity to look at the role of technical knowledge in university-industry relationships. Because this study is concerned with university-industry relationships in different parts of the country, and for different economic activities, it was important to ensure that respondents represented a random sample that was not biased against any particular part of the country or for a particular type of industrial activity. The random geographic nature of the respondents was confirmed when the distribution of the survey population was compared to that of respondents by Census Division. A chi-square statistic of 9.49 showed no significant difference between the pattern of respondents by Census Division compared to the population. Also, because of the highly interrelated nature of the chosen SIC groupings, the industry of responding firms made no difference when explaining subsequent findings.

Although part of a larger study the survey specifically asked company officials to indicate how important various sources of technical knowledge were to the development of new products and production processes. The sources of technical knowledge included: trade publications, professional or scientific journals; in-house (company) research and development; parent company research and development (R\&D); government agencies; suppliers; customers; licensed technologies; consultants; universities as institutions; and competitors. Each respondent was asked to rate each of the above sources of technical knowledge in terms of whether or not each respective source of knowledge was very important, somewhat important, a source but not important, or not a source for the company. Consequently this paper is not concerned with all the functions of a university, but focuses explicitly on the variety of knowledge source available at universities and elsewhere. In related papers that deal with the geographic dimensions of the larger study (Debbage and Rees, 1991; Rees, 1991), proximity and access to graduate students and faculty am also found to be critical factors in university-industry linkages, but they are not the primary focus of this paper.

Each company was also asked to respond to various questions that focused on the experience of company decision-makers with university-industry relationships. Specific issues included:

- the extent to which research-oriented firms are attracted to locations with strong university-industry interactions (LOCATION), 
- the satisfaction levels of companies involved in cooperative projects with universities (SATISFACTION),

- whether or not state-funded technology development programs should be affiliated with universities (AFFILIATION),

- whether company size influences how companies perceive universities as sources of technical knowledge, and also whether company size influences company satisfaction levels when involved in cooperative projects with universities.

The median employment level of the respondents was 155 persons and median sales volume was $\$ 12.6$ million. These median figures were used to distinguish smaller companies from larger companies. However; this is a relative measure, and it is important to recall that the definition of small companies is itself a moot point. The Small Business Administration defines small companies as those companies with less than 500 employees. In this research, we anticipated that as companies became larger they were more likely to have been involved with universities than smaller companies.

\section{UNIVERSITIES AND OTHER SOURCES OF TECHNICAL KNOWLEDGE}

Companies were asked to indicate whether universities and other sources of technical knowledge were important or not in the development of new products and production processes. While a four-part scaling procedure was used for this question, company responses are collapsed and each company response is rated in terms of whether a source of technical knowledge was deemed important or not important.

For 135 companies (63\% of all respondents), universities as institutions are either not an important source of technical knowledge or they are not used at all as a source of knowledge (see Table 1 ). Only 79 companies (37\% of all respondents) identified universities as important sources of technical knowledge, and of these 79 companies, only 12 suggested that universities were very important sources of technical knowledge. A majority of companies do not perceive universities as important sources of technical knowledge in the development of new products and production processes, though other factors included in the survey show that this generalization needs to be qualified. Also, open-ended questions that were part of this survey suggested that some of the reasoning for the unfavorable perception are associated with the notion that university institutions are remote to the immediate needs of industry.

\section{TABLE 1}

SOURCES OF TECHNICAL KNOWLEDGE IN THE DEVELOPMENT OF NEW PRODUCTS AND PRODUCTION PROCESSES 


\begin{tabular}{l|ll|ll} 
Trade or scientific bublications & 176 & $(82 \%)$ & 38 & $(18 \%)$ \\
Customers & 173 & $(81 \%)$ & 41 & $(19 \%)$ \\
Comnetitors & 1.31 & $(61 \%)$ & 8.3 & $(39 \%)$ \\
Subnliers & 118 & $(55 \%)$ & 96 & $(45 \%)$ \\
Consultants & 94 & $(44 \%)$ & 120 & $(56 \%)$ \\
Universitv institutions & 79 & $(37 \%)$ & 135 & $(63 \%)$ \\
Licensed technologies & 69 & $(32 \%)$ & 145 & $(68 \%)$ \\
Government agencies & 46 & $(21 \%)$ & 168 & $(79 \%)$ \\
Parent company R\&D & 33 & $(15 \%)$ & 181 & $(85 \%)$ \\
\hline
\end{tabular}

In a company's search for technical knowledge relevant to the development of new products and production processes, a variety of sources of knowledge other than universities can also play an important role. These alternative sources of information include: trade, professional or scientific journals; in-house (company) R\&D; parent company R\&D; government agencies; suppliers; customers; licensed technologies; consultants; competitors; and other sources.

Most companies considered the following sources of knowledge to be important: in-house R\&D (86\% of respondents); trade, professional and scientific journals (82\% ); and customers (81\%) (see Table 1 ). Because a majority of companies considered trade, professional, and scientific journals as important sources of technical knowledge, it can be argued that universities play an important indirect role in the development of new products and production processes. Many trade, professional and especially scientific journals are written by university researchers. Companies may value journal-related information more highly than they do university institutions per seas sources of technical knowledge, thus leading to an undercount of the value of the university. Although university institutions are viewed by some executives as unable to serve industry needs, basic university research through journals is frequently perceived as relevant to the more applied concerns of industry. Also worth noting is that when considering other issues involved in cooperative university-industry programs (e.g., licensing and patenting assistance, managerial assistance, laboratory facilities, equity investment), it is probable that the institutional role of universities will be seen as most vital.

Other than universities, a majority of companies also considered the following sources of knowledge to be unimportant: parent company R\&D (85\% ); government agencies (79\% ); and licensed technologies (68\%) (see Table 1). However parent company R\&D may not be perceived as an important source of technical knowledge simply because the majority of surveyed companies were single as opposed to multi-plant or multi-locational companies. Part of the reasoning for the perceived unimportance of government agencies may be associated with the traditional image in the private sector that government agencies are not important sources of technical knowledge.

SOURCES OF TECHNICAL KNOWLEDGE: SOME INTERRELATIONSHIPS 
It is less clear how the different sources of technical knowledge interrelate. For example, what is the role of a university as a source of technical knowledge to a company compared with other alternative sources of information? To determine the interrelationships between the various forms of technical knowledge, the data set was subjected to a chi-square test. Only those interactions that were significant at the five percent level or less are discussed further.

Many of the sources of technical knowledge are highly interrelated (see Table 2). Licensed technologies, publications and journals, customers, and universities are significantly interrelated with a majority of the other sources of information. On the other hand, some sources of technical knowledge appear to be somewhat independent and unrelated to other sources of technical knowledge. These include parent company R\&D and suppliers. Not surprisingly, the three most frequently cited sources of technical knowledge that were considered to be important are all significantly interrelated, i.e., in-house R\&D, publications and journals, and customers. Companies that considered one of these three sources of technical knowledge as important invariably rated the other two sources of information as important in the development of new products and production processes.

Although licensed technologies were not considered an important source of technical knowledge by the majority of the respondents (see Table 1), this variable was significantly interrelated with the highest number of alternative sources of information (see Table 2). If a company considered licensed technology as important in the development of new innovations in production, the company was also likely to consider publications and journals, in-house R\&D, customers, and competitors as important sources of technical knowledge. Conversely, companies that did not rate licensed technologies very highly also tended to perceive government agencies, consultants, and universities less favorably.

\section{Table 2 is omitted from this formatted document.}

While only 37 percent of the respondents cited universities as an important source of technical knowledge (see Table 1 ), when a company considered a university as an important source of information then in-house R\&D and consultants were also perceived as important (see Table 2). On the other hand, companies that did not value universities as important sources of knowledge also tended to be more likely to consider parent company $R \& D$, government agencies, and licensed technologies as less important sources of information (see Table 2). These findings seem to suggest that universities located in regions that host companies with in-house R\&D capabilities may be perceived more favorably by industry than universities without these additional supporting facilities. This also suggests that the notion of geographic agglomerations including universities are important factors in industry's search for technical knowledge (Debbage and Rees, 1991).

Few companies considered parent company R\&D and government agencies as important sources of technical knowledge. Parent company R\&D was not considered an important source of 
technical knowledge, in part, because a majority of the respondents were small companies that were not part of a larger industrial organization. Government agencies, on the other hand, may be perceived as being part of a public sector bureaucracy that is considered remote to the immediate needs of industry. Furthermore, neither source of technical knowledge was significantly interrelated with many alternative sources of information. Parent company R\&D was significantly interrelated with only two other sources of technical knowledge: government agencies and universities. Respondents that did not value parent company R\&D invariably considered government agencies and universities as unimportant in the development of new products and production processes. On the other hand, companies that did not rate government agencies very highly also tended to perceive parent company $R \& D$, licensed technologies, consultants, and universities less favorably.

A systematic pattern seems to have emerged whereby the sources of technical knowledge that are considered to be important by the majority of the respondents are highly interrelated.

Furthermore, those sources of technical knowledge that are perceived as being unimportant to the majority of the respondents are also significantly interrelated. Most companies considered inhouse R\&D, publications and journals, and customers as important sources of information in the production of new products and production processes. If a company perceived one of these sources of information as important they invariably considered all three sources as important. On the other hand, the majority of respondents perceived parent company R\&D and government agencies as unimportant to company innovation. Furthermore, if a company considered either of these two sources of information as unimportant they tended to consider the other source of technical knowledge as unimportant also.

Finally, if universities were considered to be important sources of technical knowledge, then these same companies also tended to rate in-house $R \& D$, and consultants highly. On the other hand, if universities were not considered to be important sources of technical knowledge then parent company $\mathrm{R} \& \mathrm{D}$, government agencies, and licensed technologies were also viewed less favorably.

\section{UNIVERSITY -INDUSTRY INTERRELATIONSHIPS}

Some broader characteristics of university-industry relationships may be significantly affecting how universities are perceived as sources of technical knowledge. A second objective of this paper involves relating how companies perceive universities as sources of technical knowledge to both a company's attitude towards locations with strong university-industry interactions, and also to the level of company involvement in cooperative projects with universities. To further analyze these interrelationships, three major dimensions of university-industry relationships (LOCATION, SATISFACTION, and AFFILIATION) were studied. Before analyzing the interactive effect of each of these variables on how companies perceive the role of universities as sources of technical knowledge, a brief overview of the study findings relating to LOCATION, SATISFACTION, and AFFILIATION is provided (see research approach section). 
For 98 companies (45\% of all respondents), research-oriented firms are attracted to locations with strong industry-university interactions to a great extent (LOCATION). Ninety-five companies (44\% of all respondents) indicated that research-oriented firms should be somewhat attracted to locations with strong university-industry interactions. Only 12 companies (5\% of all respondents) indicated strong university-industry interactions are of little importance.

Although the majority of respondents rated university locations highly if a company is researchoriented, only 84 companies (39\% of all respondents) indicated that they were directly involved in a cooperative project with a university. Of these 84 companies, 83 indicated that they were either very satisfied or somewhat satisfied with the university collaboration (SATISFACTION). Perhaps more importantly, 129 companies (60\% of all respondents) did not actively participate with a university in some form of industrial research. However, 133 companies indicated that if states are to continue funding state technology development centers then they should be affiliated with universities. Only 30 companies indicated that these centers should not be affiliated with universities (AFFILIATION). These findings indicate a basic level of support for university involvement with technology development centers.

To summarize the findings thus far, the nature of the relationships between universities and industry is an important, but increasingly complex, part of any state economic development stratagem. Industry tends to find locations with strong industry-university interactions important for research-oriented firms and generally considers a formal affiliation with universities as an essential ingredient in any state technology development program. However, only a minority of those companies surveyed were actively engaged to date in a cooperative project with a university, although almost all of these firms were satisfied with this arrangement. One is also reminded that a majority of companies did not consider universities as institutions as an important source of technical knowledge, although professional and scientific journals were highly rated.

It is possible that the way companies perceive LOCATION, SATISFACTION, and AFFILIATION may play a role in determining how companies perceive the role of universities as sources of technical knowledge (KNOWLEDGE). To determine the interrelationships between KNOWLEDGE and LOCATION, SATISFACTION, and AFFILIATION the variables were subjected to a series of chi-square tests. While a multiple-part scaling procedure was originally used to classify responses for each variable, company responses in this analysis are collapsed into two responses for each respective variable to facilitate chi-square analysis. The two KNOWLEDGE categories included universities being either important or not important sources of knowledge (see Table 1). The LOCATION variable rated the extent to which research-oriented firms are attracted to locations with strong university-industry interactions. Executives were asked to indicate whether such locations were very important or less important locational influences. The SATISFACTION variable measured the level of satisfaction of companies involved in cooperative projects with universities, and companies were either satisfied with the university interaction or dissatisfied/not directly involved with a university. 
AFFILIATION measured whether universities should be either affiliated or not affiliated with state-funded technology development centers in the future. Finally, only those interactions that were significant at the five percent level or less are discussed further; and based on this the only significant influences on KNOWLEDGE were LOCATION and SATISFACTION (see Table 3).

Knowledge and Location

If a company considered universities as an IMPORTANT source of technical knowledge (KNOWLEDGE), they are more likely to perceive that locations with strong university-industry interactions are very important rather than less important for research-oriented firms (46 respondents versus 33 respondents) (see Table 4). Not surprisingly, if a company considered universities as an UNIMPORTANT source of technical knowledge, they are more likely to perceive that locations with strong university-industry interactions are less important rather than very important for research-oriented firms (83 respondents versus 52 respondents). However, an important qualification is in order here. A large absolute number of companies that suggested universities were an unimportant source of technical knowledge also indicated that strong university-industry interactions were a very important location factor for research-oriented firms (52 respondents). For some companies, universities are not important sources of technical knowledge but many of these companies recognize the relative importance of an industrial location that is characterized by strong university-industry linkage, particularly for researchoriented firms.

\section{Table 3 is omitted from this formatted document.}

Knowledge and Satisfaction

The other significant influence on KNOWLEDGE was SATISFACTION. In this case, the interrelationships between these variables were straightforward and required no qualifications. Companies that considered universities IMPORTANT sources of technical knowledge were also more likely to be satisfied with their cooperative university ties rather than not satisfied or not directly involved with a university (51 respondents versus 28 respondents) (see Table 4). Conversely, companies that did not value universities as a source of technical knowledge were more likely to be either dissatisfied or not directly involved in a cooperative project with a university (103 respondents versus 32 respondents).

To summarize, companies that considered universities as useful and important sources of technical knowledge also tended to highly rate locations with strong university-industry interactions for research-oriented firms and were satisfied in their direct dealings with universities. On the other hand, companies that considered universities as unimportant sources of technical knowledge also tended to underplay the significance of locations with strong university-industry interactions and were either dissatisfied or not directly involved in a cooperative project with a university. However; do these various findings vary based on specific company characteristics? 


\section{INDUSTRY KNOWLEDGE SOURCES, UNIVERSITIES, AND COMPANY CHARACTERISTICS+}

\section{Table 4 is omitted from this formatted document.}

By studying university-industry relationships from the four different perspectives mentioned earlier (KNOWLEDGE, LOCATION, SATISFACTION, and AFFIUATION), and relating this

to individual company characteristics, it is possible to begin to understand what type of company is most likely to favor and value linkages with a university.

In the larger study, respondents were asked to list some basic company characteristics and these included:

- total sales volume $(1984,1986)$

- sales volume growth rates (1984-1986)

- total number of employees (1987)

- percent of total company sales to U.S. Department of Defense (1986)

- percent of total company sales spent on R\&D (1986).

Each of these variables was subdivided into dichotomous response categories based on the median value for each phenomenon (see Table 5). Mean values were not used because of the bias introduced by a small number of extreme values. By studying these variables, it is possible to examine the impact of company size (sales and employees); the research and governmentorientation of the company (R\&D and DOD); and relative growth rates on how a company perceives the benefits and costs of university-industry relationships and how universities are perceived as sources of technical knowledge. Based on a series of cross-tabulations and chisquare tests, only two of the four measures of how companies perceive university-industry ties were significantly related at the five percent level to any of the above company characteristics. LOCATION and AFFIUATION were not significantly related to any of the above company characteristics. Part of the reasoning for this may be related to the large number of companies that considered locations with strong industry-university interactions as important and also indicated that state technology programs should be affiliated with universities. When an overwhelming majority of respondents perceive the university-industry environment in similar ways, it is unlikely that specific company characteristics will begin to explain and highlight different experiences and attitudes.

On the other hand, KNOWLEDGE and SATISFACTION were both significantly related to company size (as defined by sales volume and employment levels). In the context of this study, a large company was defined as any firm with above median levels in sales volume and/ or employment levels. The median 1986 sales volume for the 216 surveyed companies was \$12.6 
million while the median 1987 employee total was 155 persons. How does company size influence both the way companies perceive universities as sources of technical knowledge and the satisfaction levels of companies involved in cooperative projects with universities?

\section{Table 5 is omitted from this formatted document.}

Knowledge and Company Size

If a company considered a university as an important source of technical knowledge in the development of new products and production processes, they are more likely to have a 1986 sales volume greater than \$12.6 million (45 respondents versus 26 respondents) (see Table 6). Not surprisingly, if a company considered universities as an unimportant source of technical knowledge, they are more likely to be smaller companies with sales volume less than or equal to \$12.6 million (74 respondents versus 56 respondents) (see Table 6). Similar findings were found when using 1984 sales volume and 1987 employment levels (see Table 6).

\section{Table 6 is omitted from this formatted document.}

Large companies (in terms of sales volume and employment) are more apt to perceive universities as important sources of technical knowledge relative to smaller companies. Part of the reasoning for this may be the tendency for large companies to possess the resources and capacity that cater for universities. However, although large companies are more active in university-based research, small businesses are often more product-innovative, relative to their size, than large firms. Link and Rees (1990, p. 30) in a related study concluded that "small firms appear to be able to transfer knowledge gained from their university research associations most effectively, compared to large firms, to increase the returns to their internal R\&D activities." It could also be argued from a university outreach perspective that small companies need more technical assistance.

Furthermore, an important qualification is in order. In absolute terms, more large companies perceived universities as an unimportant source of technical knowledge relative to those that considered universities an important source of technical knowledge. However this is simply due to the higher total number of companies that perceived universities as unimportant sources of technical knowledge relative to those that perceived universities more favorably.

\section{Satisfaction and Company Size}

If a company was directly involved in a cooperative project with a university and was also satisfied with this arrangement, the company was more likely to have a 1986 sales volume greater than \$12.6 million (56 respondents versus 22 respondents) (see Table 7). Not

surprisingly, if a company was not directly involved with a university or was dissatisfied with the cooperative linkage, they are more likely to be smaller companies with sales less than or equal to 
the median value (78 respondents versus 45 respondents) (see Table 7). Similar findings were found when using 1984 sales volume and 1987 employment levels (see Table 7).

Large companies are more apt to be directly involved in cooperative activities with universities and they also tend to be satisfied with this arrangement. Once more, the scale of operations and the opportunity for specialization amongst larger companies seems to facilitate and encourage linkage with universities.

\section{SUMMARY AND POUCY IMPUCA TIONS}

In recent years, university-industry relationships have emerged as a key ingredient in a wide variety of national and state-level development strategies. These strategies frequently seek to maintain a competitive advantage relative to other companies and other parts of the world (Porte 1990). The structural transformation of the United States economy and the increased emphasis on high technology production with substantial R\&D inputs has stimulated growth in sectors that stress the creation and use of knowledge-based products. Knowledge, as an increasingly important production input in the development of new products and production processes, has provided part of the rationale for an increase in the level of collaboration between universities and industry. Despite this, a comprehensive assessment of how companies perceive universities as knowledge sources has not been forthcoming. In this paper; an analysis of how 216 companies from some of the most innovative sectors of the United States economy perceived universities as sources of technical knowledge revealed a diversity of influences and factors that shape the various characteristics of university-industry collaboration.

\section{Table 7 is omitted from this formatted document.}

While universities as institutions are not commonly perceived as important sources of technical knowledge in the development of new products and production processes, trade, professional and scientific journals were perceived favorably by $82 \%$ of all respondents. The surveyed companies seemed to rate published research and journals highly, although this did not necessarily imply that companies were willing to engage in a formal arrangement or collaboration with a university institution. Only 39\% of all respondents indicated they were directly involved in a cooperative project with a university.

Those companies that did perceive universities as important sources of technical knowledge also tended to be companies with above median levels in sales volume and employment, and they also were invariably involved in some sort of cooperative project with a university. These same companies also rated in-house R\&D and consultants favorably as sources of technical knowledge. Universities located in regions that are host to several large companies with in-house $\mathrm{R} \& \mathrm{D}$ facilities may be operating in environments that are more conducive to university-industry collaboration. 
The policy implications of these findings need to be seen in the context of the larger study of which this analysis is a part (Rees, 1991). From this larger study of university-industry relationships in general, and the experience of companies with state-funded technology centers in particular; it was found that larger companies are more likely to collaborate with universities than smaller companies. Because differences between large and small companies were also evident in the results of this paper; the need for policy-makers to carefully consider firm size as an important variable in local economic development and to encourage the further involvement of small companies with universities is underscored. Since the larger study also showed a university's inability to protect the proprietary nature of research to be an important reason why more university-industry collaboration does not exist, this same perception can influence why many industrialists do not perceive universities as important sources of technical knowledge. This underscores the need for universities to continuously assess their policies towards intellectual property rights and how this affects future relationships with the private sector. The importance of trade and scientific journals as sources of technical knowledge to industry clearly shows that university research has a major indirect impact on the development of product and process technology in the private sector. It is the production of scientific research from a university, and not universities as institutions per se that is important to industry in this regard.

Since the larger study also shows that industry involvement with state technology centers does have a positive impact on product development, particularly its quality, and can indeed stimulate related research within participating companies (Rees, 1991), government policy-makers interested in fostering further university-industry collaboration should consider more information dissemination to make other decision-makers more aware of the successes. Many companies are shielded from the successes of their competitors, whereas it may be in the public interest to make success more visible. At the same time, public sector decision-makers need to recognize the skepticism with which industrialists still view government agencies as sources of knowledge as shown in these results. Again, more attention to success stories might eventually influence perceptions.

Because industrialists tend to view locations with strong university-industry interactions as important for research-oriented firms, as well as to consider formal affiliations with universities as generally important, such findings confirm the role that university-industry collaboration can play as part of a long term economic development strategy. Because the development and diffusion of knowledge does take a long time, public-policy makers should be careful not to kill university-industry programs with real potential when they use evaluation measures like jobs generated or funds matched in the short-term.

Although the analysis reported here is limited to the experience of companies in a few key linked sectors, the findings are noteworthy enough to encourage more research to analyze how companies involved in other types of university-industry programs perceive universities as sources of technical knowledge and how this knowledge transfers into increased productivity. Economic development strategies that depend on productive university-industry linkage as the 
catalyst for generating spin-off development may be doomed to failure if we do not get a clearer understanding of industry experience with universities and how key decision-makers perceive the role of universities.

\section{ENDNOTE}

1Dr. Rees would like to thank the Economic Development Administration for funding part of the research on which this paper is based. The findings and recommendations are those of the authors and do not necessarily reflect the view of EDA.

\section{References}

Berman, E. M. (1990). The economic impact of industry-funded university R \& D. Research Policy, 19, 349-355.

Debbage, K. D. and Rees, J. (1991). Company perceptions of comparative advantage by region. Regional Studies, 25, 199-206.

Dimancescu, D. and Botkin, J. (1986). The neiv alliances: America's R \& D consortia. Cambridge : Ballinger.

Feller, I. (1990a). University-industry R \& D relationships. In J.Schmandt and R.Wilson (Eds.), Growth policy in theageofhigh technology: The role of regions and states (pp. 313-343). Boston : Unwin Hyman.

Feller (1990b). Universities as engines of R \& D-based economic growth: They think they can. Research Policy, 19, 335-348.

Goldstein, H. A. and Luger, M. I. (1990). Universities as instruments of technology-based economic development policy. Paper presented at the 13th Annual Applied Geography Conference, Charlotte, North Carolina.

Lambright, W. H. and Teich, A. H. (1989). Sdence, technology and state economic development. Policy Studies Journal, 18, 135-147.

Link, A. N. and Rees, J. (1990). Firm size, university based research, and the returns to R \& D. Small Business Review, 2, 25-31. Luger, M. I. and Goldstein, H. A. (1990). Technology in the garden: Research parks and regional economic development. Final Report to the Ford Foundation Program in Human Governance and Public Policy. Mansfield, E. (1991). Academic research and industrial innovation. Research Policy, 20, 1-12.

National Science Board. (1982). Selected studies in university-industry research relationships. Washington, DC : U.S. Government Printing Office. 
Paget, K. M. (1990). State government-university cooperation. In Schmandt, J. and Wilson, R. (Eds.), Growth policy in the age of high technology: The role of regions and states (pp. 344380). Boston : Unwin Hyman.

Porter, M. (1990). The competitive advantage of nations. New York : The Free Press.

Rees, J. (Ed.) (1986). and policy. Totowa , NJ : Rowman and Littlefield.

Rees, J. (1989). Industry experience with technology research centers. Final Report to the United States Department of Commerce, Economic Development Administration, Technical Assistance and Research Division.

Rees, J. (1991). Universities and state technology centers: What industry thinks. Economic Development Commentary, 15, 4-11.

Roessner, J. D. (1989). Evaluating government innovation programs: Lessons from the U.S. experience. Research Policy, 18, 343-359.

Roessner, J. D. and Bean, A. S. (1990). Industry interactions with federal laboratories. Technology Transfer, Fall, 5-14.

Schmandt, J. and Wilson, R. (Eds.), (1990). Growth policy in the age of high technology: The role of regions and states. Boston : Unwin Hyman.

Sy, K. J. (1987). University-state linkages revisited: A model of faculty participation in policymaking. Polky Studies Journal, 16, 3-26. 